\title{
Research Progress on Nutrient Composition of Green Pepper
}

\author{
Zhengwei Xie ${ }^{\mathrm{a}}$, Wanyun Peng ${ }^{\mathrm{b}^{*}}$, Qianqian $\mathrm{Ma}^{\mathrm{c}}$, Zhide Wang ${ }^{\mathrm{d}}$, Peng $\mathrm{Wu}^{\mathrm{e}}$ \\ Dazhou Academy of Agricultural Sciences, Dazhou, Sichuan, China
}

\begin{abstract}
Green pepper is an important traditional spices in China, with food flavor and various pharmacological functions. Based on the literature at home and abroad, the nutritional components of green pepper are systematically reviewed to provide a theoretical basis for the comprehensive utilization of green pepper.
\end{abstract}

\section{Introduction}

Green pepper (ZanthoxylumschinifoliumSiebetZucc) for the Rutaceae pepper plant, Also known as pepper, cliff pepper, wild pepper, green pepper, dog pepper, Because its fruit ripens for the cyan [1], mainly produced in Chongqing Jiangjin, Sichuan Jinyang, Emei, Liaoning Dandong, Yunnan Province on both sides of the Jinsha River and other places [2]. Green pepper peel is the raw material of essence and spice, seed is good woody oil, oil cake can be used as fertilizer or feed, leaf can be used as seasoning, edible or making pretzel tea instead of fruit, and it is also an important soil and water conservation tree in arid and semi-arid mountainous area [3]. Green pepper products have a strong spicy flavor, can calm the smell of mutton, is cooking seafood, fishy, meat and cold food seasoning, but also folk pickled indispensable ingredients [4]. At the same time also has the pharmacological function, has the literature record may be used "breaks the stasis knot, the appetizer, treats the day to walk the temperature disease, the postpartum lodging blood, treats the heart and abdomen qi, strengthens the yang, treats the Yin sweat, warms the waist knee, reduces the stool. Now commonly used in hospital abdominal pain, vomiting diarrhea, warm pain, insecticidal antipruritic, insect abdominal pain, ascariasis; external treatment of eczema pruritus, also have a certain effect on delaying aging [5].

In recent years, more and more research results show that green pepper contains volatile oil, vinegar, alkaloids, lignans, coumarins, trace elements and other active substances, with antioxidant, anti-inflammatory, anti- tumor, insecticidal and bacteriostatic and anti-corrosion activities [6-7]. This paper will analyze the nutritional components of green pepper and provide a theoretical basis for the comprehensive utilization of green pepper.

\section{Nutrients of Green Pepper}

\subsection{Amino acids}

Amino acids are important components of protein, polypeptide and $\mathrm{R} \mathrm{N} \mathrm{A} 、 \mathrm{D} \mathrm{N} \mathrm{A,} \mathrm{which} \mathrm{play} \mathrm{an}$ important role in life activities. The amino acids in green pepper are complete, among which the higher contents are aspartate, glutamate, lysine, leucine and histidine. Li Qian et al. compared the amino acid composition of green pepper in different producing areas. the results showed that the amino acid content of protein in hanyuan green pepper was the highest $(\mathrm{P}<0.05)$, and the content of essential amino acid, sweet amino acid and sour amino acid was significantly higher than that in other producing areas, see table 1 [8].Li Peihong et al. studied the amino acids of the tender buds of Zanthoxylum bungeanum from bamboo leaves. The results showed that the wild materials of Zanthoxylum bungeanum from nine leaves were all containing 18 kinds of amino acids, and the contents were higher than those of Toona sinensis. At the same time, the results showed that the proportion of amino acids in the protein of Jiuye green pepper and rattan pepper was reasonable and the quality was [9].

Table 1 Amino acid content of Green Pepper in Different Origin

\begin{tabular}{|c|c|c|c|c|c|c|c|}
\hline \multirow{2}{*}{$\begin{array}{l}\text { Amino acid } \\
\text { content }(\%)\end{array}$} & \multicolumn{6}{|c|}{ Origin } & \multirow[b]{2}{*}{$\mathrm{T}$} \\
\hline & Jinyang & & Hongya & Emei & Hanyuan & Chongqing & \\
\hline Aspartate & $\begin{array}{l}0.74 \\
0.0006 \mathrm{~d}\end{array}$ & \pm & $0.70 \pm 0.003 b$ & $0.71 \pm 0.002 \mathrm{c}$ & $0.83 \pm 0.003 \mathrm{e}$ & $0.63 \pm 0.0006 \mathrm{a}$ & 1.29 \\
\hline Glutamate & 0.65 & \pm & $0.55 \pm 0.02 b$ & $0.69 \pm 0.004 \mathrm{e}$ & $0.62 \pm 0.002 \mathrm{c}$ & $0.49 \pm 0.004 \mathrm{a}$ & 1.41 \\
\hline
\end{tabular}

\footnotetext{
*Wanyun Peng: 2670042314@qq.com

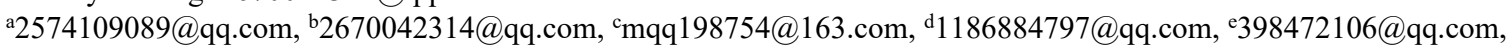




\begin{tabular}{|c|c|c|c|c|c|c|}
\hline & $0.0006 \mathrm{~d}$ & & & & & \\
\hline Glycine & $0.33 \pm 0.00 \mathrm{c}$ & $0.32 \pm 0.002 b$ & $0.33 \pm 0.001 \mathrm{c}$ & $0.40 \pm 0.002 \mathrm{~d}$ & $0.28 \pm 0.001 \mathrm{a}$ & 1.41 \\
\hline Alanine & $0.23 \pm 0.00 \mathrm{~d}$ & $0.22 \pm 0.001 \mathrm{c}$ & $\begin{array}{ll}0.19 & \pm \\
0.0005 \mathrm{~b} & \end{array}$ & $0.24 \pm 0.0006 \mathrm{e}$ & $0.17 \pm 0.0006 a$ & 1.40 \\
\hline Cysteine & $0.02 \pm 0.00 \mathrm{~d}$ & $0.01 \pm 0.0006 \mathrm{a}$ & $0 . .2 \pm 0.00 \mathrm{c}$ & $0.01 \pm 0.00 \mathrm{a}$ & $0.014 \pm 0.00 \mathrm{~b}$ & 1.69 \\
\hline Valine & $0.18 \pm 0.00 \mathrm{c}$ & $0.17 \pm 0.0006 b$ & $\begin{array}{ll}0.18 & \pm \\
0.0006 \mathrm{~d} & \end{array}$ & $0.21 \pm 0.001 \mathrm{e}$ & $0.16 \pm 0.0006 \mathrm{a}$ & 1.36 \\
\hline Isoleucine & $\begin{array}{ll}0.14 & \pm \\
0.001 \mathrm{~d} & \end{array}$ & $0.13 \pm 0.0006 \mathrm{~b}$ & $\begin{array}{ll}0.14 & \pm \\
0.0006 \mathrm{~d} & \end{array}$ & $0.17 \pm 0.00 \mathrm{e}$ & $0.12 \pm 0.00 \mathrm{a}$ & 1.41 \\
\hline leucine & $\begin{array}{ll}0.26 & \pm \\
0.001 \mathrm{~d} & \end{array}$ & $0.23 \pm 0.001 \mathrm{c}$ & $0.25 \pm 0.001 \mathrm{c}$ & $0.31 \pm 0.001 \mathrm{e}$ & $0.22 \pm 0.001 \mathrm{a}$ & 1.39 \\
\hline Tyrosine & $\begin{array}{ll}0.07 & \pm \\
0.0006 \mathrm{~d} & \end{array}$ & $0.06 \pm 0.00 \mathrm{~b}$ & $0.07 \pm 0.001 \mathrm{e}$ & $0.06 \pm 0.0006 \mathrm{c}$ & $0.05 \pm 0.001 \mathrm{a}$ & 1.37 \\
\hline Phenylalanine & $0.14 \pm 0.00 \mathrm{~b}$ & $0.13 \pm 0.0006 \mathrm{a}$ & $\begin{array}{ll}0.14 & \pm \\
0.0006 \mathrm{~b} & \end{array}$ & $0.17 \pm 0.001 \mathrm{c}$ & $0.13 \pm 0.001 \mathrm{a}$ & 1.31 \\
\hline lysine & $\begin{array}{l}0.37 \\
0.006 \mathrm{a}\end{array}$ & $0.42 \pm 0.002 b$ & $0.39 \pm 0.02 \mathrm{ab}$ & $0.53 \pm 0.02 \mathrm{c}$ & $0.36 \pm 0.015 \mathrm{a}$ & 1.47 \\
\hline Histidine & $\begin{array}{l}0.13 \\
0.001 \mathrm{a}\end{array}$ & $0.13 \pm 0.001 \mathrm{c}$ & $0.12 \pm 0.002 \mathrm{a}$ & $0.15 \pm 0.0006 \mathrm{~d}$ & $0.12 \pm 0.003 b$ & 1.26 \\
\hline Arginine & $0.46 \pm 0.01 \mathrm{~d}$ & $0.33 \pm 0.002 b$ & $0.37 \pm 0.003 c$ & $0.28 \pm 0.01 \mathrm{a}$ & $0.33 \pm 0.005 b$ & 1.62 \\
\hline Proline & $\begin{array}{l}0.005 \quad \pm \\
0.00 \mathrm{a}\end{array}$ & $0.005 \pm 0.00 \mathrm{a}$ & $0.005 \pm 0.00 \mathrm{a}$ & $0.006 \pm 0.00 \mathrm{~b}$ & $0.005 \pm 0.0006 \mathrm{a}$ & 1.28 \\
\hline $\begin{array}{l}\text { Total amino } \\
\text { acids }\end{array}$ & $3.76 \pm 0.05 \mathrm{c}$ & $3.39 \pm 0.02 b$ & $3.71 \pm 0.02 \mathrm{c}$ & $4.15 \pm 0.01 \mathrm{~d}$ & $3.12 \pm 0.02$ & 1.33 \\
\hline $\begin{array}{l}\text { Essential } \\
\text { amino acid } \\
\text { content }\end{array}$ & $\begin{array}{ll}1.26 & \pm \\
0.002 b & \end{array}$ & $1.26 \pm 0.028 \mathrm{~b}$ & $1.28 \pm 0.017 \mathrm{~b}$ & $1.62 \pm 0.017 \mathrm{c}$ & $1.15 \pm 0.015 \mathrm{a}$ & 1.41 \\
\hline $\begin{array}{l}\text { Sweet amino } \\
\text { acid content }\end{array}$ & $2.04 \pm 0.05 \mathrm{c}$ & $1.946 \pm 0.027 \mathrm{~b}$ & $2.04 \pm 0.021 \mathrm{c}$ & $2.33 \pm 0.016 \mathrm{~d}$ & $1.6 \pm 0.012 \mathrm{a}$ & 1.46 \\
\hline $\begin{array}{l}\text { Bitter amino } \\
\text { acid content }\end{array}$ & $\begin{array}{l}1.33 \\
0.015 \mathrm{~d}\end{array}$ & $1.146 \pm 0.006 b$ & $1.22 \pm 0.005 \mathrm{c}$ & $1.34 \pm 0.012 \mathrm{~d}$ & $1.11 \pm 0.023 \mathrm{a}$ & 1.21 \\
\hline Acid content & $\begin{array}{ll}1.38 & \pm \\
0.001 \mathrm{c} & \end{array}$ & $1.25 \pm 0.015 b$ & $\begin{array}{ll}1.398 & \pm \\
0.005 \mathrm{~d} & \end{array}$ & $1.43 \pm 0.006 \mathrm{e}$ & $1.122 \pm 0.004 \mathrm{a}$ & 1.28 \\
\hline
\end{tabular}

\subsection{Fatty acids}

Green pepper seeds contain $27.1 \%$ oil, $18.7 \%$ crude protein, $30.23 \%$ crude fiber (shell), $15 \%$ 20\% waxy (shell), about $10 \%$ moisture, ash and volatile matter. Green pepper seed oil is rich in unsaturated fatty acids, It has high nutritional value and health care function. Analysis of fatty acid components of pepper seed oil by gas chromatography-mass spectrometry $(\mathrm{G} \mathrm{C}-\mathrm{M} \mathrm{S})$, The results showed that the fatty acids in Zanthoxylum bungeanum seed oil were mainly composed of palmitoleic acid, oleic acid and linoleic acid, And the content of unsaturated fatty acids was $78.4 \%$, accounting for $47.8 \%[10]$ of total fatty acids. Ma Chuanguo and so on extracted pepper seed skin, seed kernel contained oil, The physical and chemical indexes of skin oil and kernel oil were determined, It was found that linoleic acid was very low in the oil, The common oils contain about $20 \%$ of the common palmitoleic acid, The unsaturated acid

\subsection{Protein}

Green pepper is rich in protein, but its content is obviously different because of its location or origin. $\mathrm{Li}$ Qian et al. determined the protein in green pepper from different producing areas. The results showed that the protein content of green pepper in different producing areas was 10.96-19.27 and the maximum difference multiple was 1.76, the difference was [8] significantly.Deng Zhenyi and others determined the protein content in different parts of Zanthoxylum bungeanum, the results showed that the protein content of pericarp was relatively high, among which the crude protein content in the pericarp of Zanthoxylum bungeanum produced by Hancheng $\mathrm{g} / \mathrm{kg}$. Shaanxi Province was as high as 130.60 And the protein content of tender stem and leaf is lower, see table 2 [12]. This further shows that the variety and growth environment 
have a great impact on the content of protein and other nutrients in Zanthoxylum bungeanum. The protein content of Zanthoxylum bungeanum seed is low, but its content will increase greatly after degreasing, and the protein types in seed kernel are various.Kou Mingyu and others studied the protein separation and functional properties of Zanthoxylum bungeanum seeds. The results showed that the protein content in Zanthoxylum bungeanum seeds was low, and the optimal parameter [13] for extracting higher protein content was obtained.

Table 2 Protein Content in Zanthoxylum bungeanum from Different Origin

\begin{tabular}{cc}
\hline Origin & Protein content $/ \mathrm{g} \cdot \mathrm{kg}-1$ \\
\hline Fengxian & 122.0 \\
Chengcang & 83.1 \\
Hancheng & 130.6 \\
Taibai & 90.2 \\
Hanyuan & 86.9 \\
Wenchuan & 106.2 \\
Maoxian & 85.0 \\
Tianshui & 62,9 \\
Wudu & 94.9 \\
Taian & 113.2 \\
Ruicheng & 126.4 \\
\hline
\end{tabular}

\subsection{Mineral elements}

Mineral elements play an important role in cell metabolism, biosynthesis and physiological function of human body. They are components of various enzymes, which can promote metabolism and enhance the [14] of immune ability.Li Qian et al. detected the content of mineral elements in green pepper. The results showed that 10 kinds of essential elements were detected in green pepper. The group of constant elements in essential mineral elements included calcium, potassium, sodium, magnesium, and trace elements included iron, zinc, copper, manganese and selenium, among which the content of sodium was the highest, see table 3 [8].According to the research of Ningjiangang et al, the content of iron, copper and zinc in the peel of pepper in Huixian County, Henan Province is slightly lower than that of pepper seed, and the content of manganese is higher than that of pepper seed [15]. Tu Yulin et al showed that the content of iron and manganese in the peel of Dingtan pepper in Zhenfeng County, Guizhou Province is obviously higher than that of its seed, and the zinc content is lower than that of seed [16]. This indicates that the mineral element composition and content of Zanthoxylum bungeanum are closely related to their species, location and origin.

Table 3 Content of Mineral Elements in Green Pepper from Different Origin

\begin{tabular}{|c|c|c|c|c|c|c|}
\hline \multirow{2}{*}{$\begin{array}{l}\text { Types of } \\
\text { mineral } \\
\text { elements }\end{array}$} & \multicolumn{5}{|c|}{ Origin } & \multirow[b]{2}{*}{$\mathrm{T}$} \\
\hline & Jinyang & Hongya & Emei & Hanyuan & Chongqing & \\
\hline $\begin{array}{c}\text { Magnesium } \\
(\%)\end{array}$ & $\begin{array}{c}0.35 \pm \\
0.02 \mathrm{c}\end{array}$ & $0.25 \pm 0.01 \mathrm{a}$ & $0.26 \pm 0.01 \mathrm{a}$ & $0.24 \pm 0.01 \mathrm{a}$ & $0.28 \pm 0.01 \mathrm{~b}$ & 1.47 \\
\hline $\begin{array}{r}\text { Copper } \\
(\mathrm{mg} / \mathrm{kg})\end{array}$ & $\begin{array}{c}18.63 \pm \\
0.25 \mathrm{e}\end{array}$ & $14.03 \pm 0.25 \mathrm{~d}$ & $11.83 \pm 0.15 \mathrm{c}$ & $11.27 \pm 0.15 b$ & $8.29 \pm 0.07 \mathrm{a}$ & 2.25 \\
\hline $\begin{array}{c}\text { Iron } \\
(\mathrm{mg} / \mathrm{kg})\end{array}$ & $\begin{array}{c}39.53 \pm \\
0.60 \mathrm{c}\end{array}$ & $30.83 \pm 0.31 \mathrm{~b}$ & $30.83 \pm 0.31 b$ & $50.4 \pm 0.36 \mathrm{~d}$ & $27 \pm 0.3 \mathrm{a}$ & 1.87 \\
\hline $\begin{array}{l}\text { Manganese } \\
(\mathrm{mg} / \mathrm{kg})\end{array}$ & $\begin{array}{c}40.17 \pm \\
0.31 \mathrm{~d}\end{array}$ & $37.37 \pm 0.45 \mathrm{c}$ & $37.37 \pm 0.45 c$ & $27 \pm 0.20 \mathrm{a}$ & $47.8 \pm 0.26 \mathrm{e}$ & 1.77 \\
\hline $\begin{array}{c}\text { Zinc } \\
(\mathrm{mg} / \mathrm{kg})\end{array}$ & $\begin{array}{c}25.77 \pm \\
0.25 d\end{array}$ & $25.3 \pm 0.2 \mathrm{c}$ & $20.97 \pm 0.25 \mathrm{a}$ & $25.93 \pm 0.15 \mathrm{~d}$ & $22.9 \pm 0.26 \mathrm{e}$ & 1.24 \\
\hline $\begin{array}{l}\text { Calcium } \\
(\mathrm{mg} / \mathrm{kg})\end{array}$ & $\begin{array}{l}0.69 \pm \\
0.01 \mathrm{~b}\end{array}$ & $0.6 \pm 0.01 \mathrm{a}$ & $0.73 \pm 0.01 \mathrm{c}$ & $0.61 \pm 0.01 \mathrm{a}$ & $0.78 \pm 0.01 \mathrm{~d}$ & 1.3 \\
\hline $\begin{array}{c}\text { Phosphorus } \\
(\%)\end{array}$ & $\begin{array}{l}0.16 \pm \\
0.01 \mathrm{a}\end{array}$ & $0.20 \pm 0.01 b$ & $0.23 \pm 0.01 \mathrm{c}$ & $0.17 \pm 0.01 \mathrm{a}$ & $0.19 \pm 0.01 b$ & 1.43 \\
\hline $\begin{array}{l}\text { Potassium } \\
(\%)\end{array}$ & $\begin{array}{l}1.6 \pm \\
0.04 \mathrm{~b}\end{array}$ & $1.84 \pm 0.04 \mathrm{c}$ & $1.44 \pm 0.04 \mathrm{a}$ & $1.8 \pm 0.04 \mathrm{c}$ & $1.4 \pm 0.04 \mathrm{a}$ & 1.31 \\
\hline $\begin{array}{l}\text { Sodium } \\
(\mathrm{mg} / \mathrm{kg})\end{array}$ & $68 \pm 4 d$ & $44 \pm 4 c$ & $20 \pm 0.00 \mathrm{a}$ & $32 \pm 0.00 \mathrm{~b}$ & $32 \pm 0.00 \mathrm{~b}$ & 3.4 \\
\hline $\begin{array}{l}\text { Selenium } \\
(\mathrm{mg} / \mathrm{kg})\end{array}$ & $\begin{array}{l}0.007 \pm \\
0.0003 \mathrm{~b}\end{array}$ & $0.009 \pm 0.0004 \mathrm{c}$ & $0.007 \pm 0.0002 b$ & $0.003 \pm 0.0015 \mathrm{a}$ & $0.003 \pm 0.0002 \mathrm{a}$ & 3.12 \\
\hline
\end{tabular}

\subsection{Vitamin}

Vitamin is an essential organic compound, and because metabolism can not be produced, it must be 
supplemented by food from the outside world. The green pepper is rich in multivitamins. Deng Zhenyi and others analyzed the main components of the tender bud of Zanthoxylum bungeanum. The results showed that the green pepper contains carotene, vitamin B and vitamin D, among which the vitamin $\mathrm{D}$ is higher than that of fresh mushroom, see table 4 [17]. Studies have shown that the content of vitamin $\mathrm{C}$ in fresh pepper is significantly higher than that in dried pepper peel and seeds. Vitamin e has strong antioxidant effect and can inhibit the automatic oxidation process in the body. Therefore, it is an important substance to prevent the harmful effect of oxidation group and peroxide on the body, which is very beneficial human health [18].

Table 4 Content of Main Nutrient Components of Peppers and Fresh Lentinus edodes

\begin{tabular}{|c|c|c|c|c|c|c|c|}
\hline Category & $\begin{array}{l}\text { Protein } / \mathrm{g} \cdot \mathrm{kg}- \\
1\end{array}$ & $\begin{array}{l}\text { Fat } \\
/ \mathrm{g} \cdot \mathrm{kg}-1\end{array}$ & $\begin{array}{l}\text { Synthesis of } \\
\text { compounds } / \mathrm{g} \cdot \mathrm{kg} \text { - } \\
1\end{array}$ & $\begin{array}{l}\text { Cellulose } \\
/ \mathrm{g} \cdot \mathrm{kg}-1\end{array}$ & $\begin{array}{l}\text { Carotene } \\
/ \mathrm{mg} \cdot \mathrm{kg}-1\end{array}$ & $\begin{array}{l}\text { VB1 } \\
/ \mathrm{mg} \cdot \mathrm{kg}-1\end{array}$ & $\begin{array}{l}\text { VD } \\
/ \mathrm{mg} \cdot \mathrm{kg}-1\end{array}$ \\
\hline Pepper bud & 87.3 & 8.41 & 21.1 & 15.8 & 179.6 & 1.23 & 34.67 \\
\hline $\begin{array}{l}\text { Fresh } \\
\text { mushrooms }\end{array}$ & 15.0 & 4.0 & 54.0 & 6.0 & - & 6.4 & 0 \\
\hline
\end{tabular}

\section{Outlook}

To sum up, green pepper contains a variety of nutrients, and high nutritional value, unique flavor, significant biological activity. In the later stage of food processing, it is necessary to combine the nutrients of green pepper to make comprehensive utilization, effectively integrate the new technology of modern food processing, and improve the added value of green pepper.Peng Huirong and others determined the indexes of Panthoxylum bungeanum and compared with 10 kinds of common tender stem and leaf vegetables, it was concluded that Panthoxylum bungeanum is an ideal vegetable with high nutritional value[19].

\section{References}

1. Sun Bingyin, Kang Kegong, Li Liping.Comparative Study on Main Nutrients of Green and Red Pepper [J].] and Red Pepper Shaanxi Agricultural Science 2006(3):29-30.

2. Yao Jia, Pu Biao. Research Progress of Green Pepper]. Chinese condiments ,2010.35(6): 35-40 .

3. Shi Jinsong, Gu Gong Ping, $\mathrm{Wu}$ Suling, et al. Investigation on Resources and Utilization of Zanthoxylum bungeanum [J] Wild Plant Resources in China ,2003,22(5):6_8

4. Chang Jianwen, Tian Yutang. [M].] Cultivation Beijing: China Forestry Press ,1990.2-3

5. Pharmacopoeia Committee of the Ministry of Health of the people's Republic of China. Pharmacopoeia of the People's Republic of China (1990 Edition)[ M]. Beijing: People's Health Publishing House, Chemical Industry Press ,1990,133.

6. Guo $\mathrm{T}$, Deng Y X , Xie H ,et al.Antinociceptive and anti-inflammatory activities of ethyl acetate fraction from Zanthoxylum armatum in mice[J]. Fitoterapia ,2011,82(3): 347-351.

7. Study on Chemical Composition and Pharmacodynamics of Zanthoxylum bungeanum by
Yuan Juanli and J]. Wang Siwang Advances in Modern Biomedicine,2010,10(3):552-554.

8. Li Qian, Pu Biao. Comparative Study on the Main Nutrients of Green Pepper from Different Origin [J].] of China Chinese condiments ,2011,36(10):13-17.

9. Li Peihong, Chen Zheng, Gong Xia, Tang Wei, Yang Daiyu. A Study on the Nutrient Composition of Panthoxylum bungeanum from Bamboo Leaf J]. Sichuan Agricultural Science and Technology ,2017(12):32-34.

10. Ma Yangmin, Zhang Qiaoyun, Zhu Junfeng. GCMS analysis of fatty acid component [J].] of pepper seed oil Food and grease ,2010(8):40-41...

11. Ma Chuanguo, Bi Yanlan, Lin Min cut, etc. Chemical constituents analysis of pepper seed peel oil and kernel oil [J].]1 Journal of Zhengzhou Institute of Engineering ,2002,23:39-42

12. Comparative Study on Main Nutrients of Zanthoxylum bungeanum from Different Origin [J].] by Deng Zhenyi, Sun Bingyin, Kang Kegong, et al Journal of Northwest Agriculture ,2005,14(3):107109.

13. Study on Protein Separation and Functional Properties of Zanthoxylum bungeanum Seed [D].] by Kou Ming-chueh Chongqing: Southwest University ,2006.2.4 Mineral Elements

14. Yang Yuexin, Wang Guangya, Pan Xingchang Chinese Food Composition Table M]. Beijing: Peking University Medical Press ,2002:209.

15. Ning Jiangang, Wei Yongsheng. Analysis and determination of mineral elements [J].] in Zanthoxylum bungeanum by ICP-OES method Food Industry Science and Technology ,2012,33(4):73-75.

16. Study on Nutrient Components and Trace Elements of Zanthoxylum bungeanum by Tu Yulin Dingtan [J].]; and Journal of Guizhou Normal University: Natural Science Edition ,2000,18(4):32-36.

17. Analysis of Main Nutrient Components of Peppers, such as Deng Zhenyi, Sun Bingyin, Kang Kegong and J]. Journal of Northwest Forestry University 20(1):179-180.

18. Study on Nutrient Components and Trace Elements of Zanthoxylum bungeanum by Tu Yulin Dingtan 
[J].]; and Journal of Guizhou Normal University: Natural Science Edition ,2000,18(4):32-36
19. Peng Huirong, Chen Xun. A study on the nutritional composition of young stem and leaf of Zanthoxylum bungeanum Anhui Agricultural 